\title{
Environmental Factors Influencing Antibiotic Resistant Bacterial Pathogens in Polluted Lake Manzala, Egypt
}

\section{Mahmoud MM Zaky ${ }^{1 *}$ and Mohamed AM Salem ${ }^{2}$}

${ }^{1}$ Botany Department, Faculty of Science, Port-Said University, Port-Said, Egypt

${ }^{2}$ Quality Sector, Water and Wastewater company-Canal Provinces, Egypt

\begin{abstract}
Lake Manzala is considered one of the most important Costal lakes, in the northern part of Egypt. It suffers from high load of pollutants from different sources such as sewage, industrial and agricultural wastes. In this study, physicochemical characterization of lake water revealed high levels of pollution in different sampling sites such as, $\mathrm{pH}$, TSS, TDS, ammonia ,nitrates, sulfates, alkalinity, chlorides, calcium and magnesium.

Bacterial count such as TVB and fecal coliform of water and fishes of the lake revealed high contamination in Lake Manzala, a total of 90 isolates were identified and resulted in different bacterial pathogens such as, E. coli, Proteus mirabilis, Sphomonas paucimobilis, Citrobacter freunii, Erwinia sp., Pasturella sp. and Pseudomonas sp.
\end{abstract}

Antibiogram was done for all isolates using eight antibiotics such as penicillin, ampicillin, cefotaxime, chloramphenicol, rifampin, tetracycline, streptomycin and gentamicin.

The result showed a high resistant pattern among different species which are harboring plasmid DNA. This is an indication that these bacterial pathogens have risk factors in the communities around Lake Manzala.

\section{Introduction}

Lake Manzala is a shallow costal lake that consisting of thirty basins with depths ranging from 0.7 to $3 \mathrm{~m}$ in depth, the deepest areas resting in the navigation canal. It is situated east of the Nile River's Delta, between the Damitta branch of the Nile River and the Suez Canal. The Mediterranean Sea is immediately north of the narrow peninsula which separates the two bodies of water. Lake Manzala did not exist before the $6^{\text {th }}$ century $\mathrm{AD}$, before then it was an area of cultivated land with fertile soil, tectonic plate movement caused an earthquake that created the lake.

Although the lake is still considered as the largest of the Egyptian Delta Lakes, its area has been gradually decreased. Extensive land reclamation during the last century has reduced the lake surface area to less than half of its original size. In 1900's, its area was estimated at about $1,709.4 \mathrm{~km}^{2}$. By the end of the previous century, the area of the lake was estimated to be $1000 \mathrm{~km}^{2}$. The area of the open water is only $742.8 \mathrm{~km}^{2}$ due to the presence of a large number of islets in the lake. During the last decade, the reclamation is progressing at an accelerating pace where land had subsequently been created and islands enlarged. Creation of canals and drains such as the Bahr El-Bakar drain, the Sirw drain, the Ramsis drain and the Hadous drain has created an eutrophic condition and low salinity levels in the lake. The areas around the drain outlets in the south and west are characterized by brackish water and the areas in the northeast, near the sea outlets, are saline [1].

The Lake suffers from water pollution induced by agricultural drainage, industrial wastes and sewage and has been shown to be contaminated by persistent organochlorine pollutants [2].This pollution condition of the lake has increased bacterial content particularly that of pathogenic bacterial indicators, such as the fecal coliforms, E.coli, Enterococci and Clostridium perfringes and is manifested in the water as well as in the fish population [3]. pathogenic species such as, Aeromonas hydrophila and Aeromonas sobria, Pseudomonas aeruginosa, Pseudomonas fluorescence and Vibrio anguillarum, were present in the gills, intestines and flesh of the fish samples. The specimens exhibited toxigenic characteristics as well as multi-drug resistance which could explain the marked reduction of fish and the increase of diarrhoeal diseases among human populations residing in the north eastern coast of Egypt [4-6]. This study aims at characterization of microbial pollution of Lake Manzala, focusing on the antibiotic resistant bacterial strains.

\section{Materials and Methods}

Seasonally during the year 2014, water samples were taken from Kapoty, Bashtier, Mataryia and Gamil outlet areas, fish samples were collected from El-Bashtier Area and El-Mataryia Area. The selected sites are host to significant populations around the lake and receive various types of pollutants which negatively affect the condition of the lake and human health.

\section{Sampling sites}

El-Kapoty Area Samples were taken from the end of the junction canal, which connects the Suez Canal with Lake Manzala; the main source of pollution in this area comes from the city of Port-Said. Effluents such as sewage water and industrial wastes from multiple factories are disposed of in this area of the Lake. This site is close to El-Kapoty village, a fishing village in Port-Said, where they dispose of raw sewage directly into the Lake water. El-Bashtier Area is considered a midpoint between the El-Kapoty and the Mataryia areas; it receives water currents from different directions resulting in high water levels. The depth reaches three meters and is part of the navigation canal. The area has many islets which are inhabited by people who work in the fishing and raise animals, El-Mataryia area is considered the fresh-

*Corresponding author: Mahmoud MM Zaky, Botany Department, Faculty of Science, Port-Said University, Port-Said 42111, Egypt, Tel: 0663657602; E-mail: Zakymahmoud67@gmail.com

Received August 31, 2015; Accepted November 09, 2015; Published November 12, 2015

Citation: Zaky MMM, Salem MAM (2015) Environmental Factors Influencing Antibiotic Resistant Bacterial Pathogens in Polluted Lake Manzala, Egypt. J Bacteriol Parasitol 6: 249. doi: 10.4172/2155-9597.1000249

Copyright: (c) 2015 Zaky MMM, et al. This is an open-access article distributed under the terms of the Creative Commons Attribution License, which permits unrestricted use, distribution, and reproduction in any medium, provided the original author and source are credited. 
water part of the Manzala Lake; however, it receives high amounts of different types of pollutants. Untreated sewage from the El Dakahlyia governorate empties here as well as 6 million $\mathrm{m}^{3} /$ day of industrial and agricultural waste from the El-Siwr, Hadous, Ramsis and Bahr El-Bakar drains. The drains empty into the El Genka reservoir, a part of the lake that is characterized by vast vegetation composed of reeds and other aquatic plants like the water hyacinth, this area is particularly important for fishing, especially the fishing of Tilapia spp.

Gamil outlet is considered the adjoining part of the lake with sea water coming from Mediterranean Sea (Figure 1).

\section{Sampling methods}

Water samples from each site were taken in clean sterile one litre glass bottles and transported from the lake to the laboratory within six hours. The bottles were kept in ice bags and ice jackets for direct examination. Fish samples were taken from the El Bashtier area and the El Mataryia area. Once the fish samples were collected they were immediately packed in sterile polyethylene cases and preserved in ice. All samples collected were transported, homogenized and prepared for immediate bacteriological analysis, using $0.8 \%$ saline for the pour plate method.

Water samples were directly diluted with $0.8 \%$ saline distilled water for bacterial counting using the dilution method and pour plate

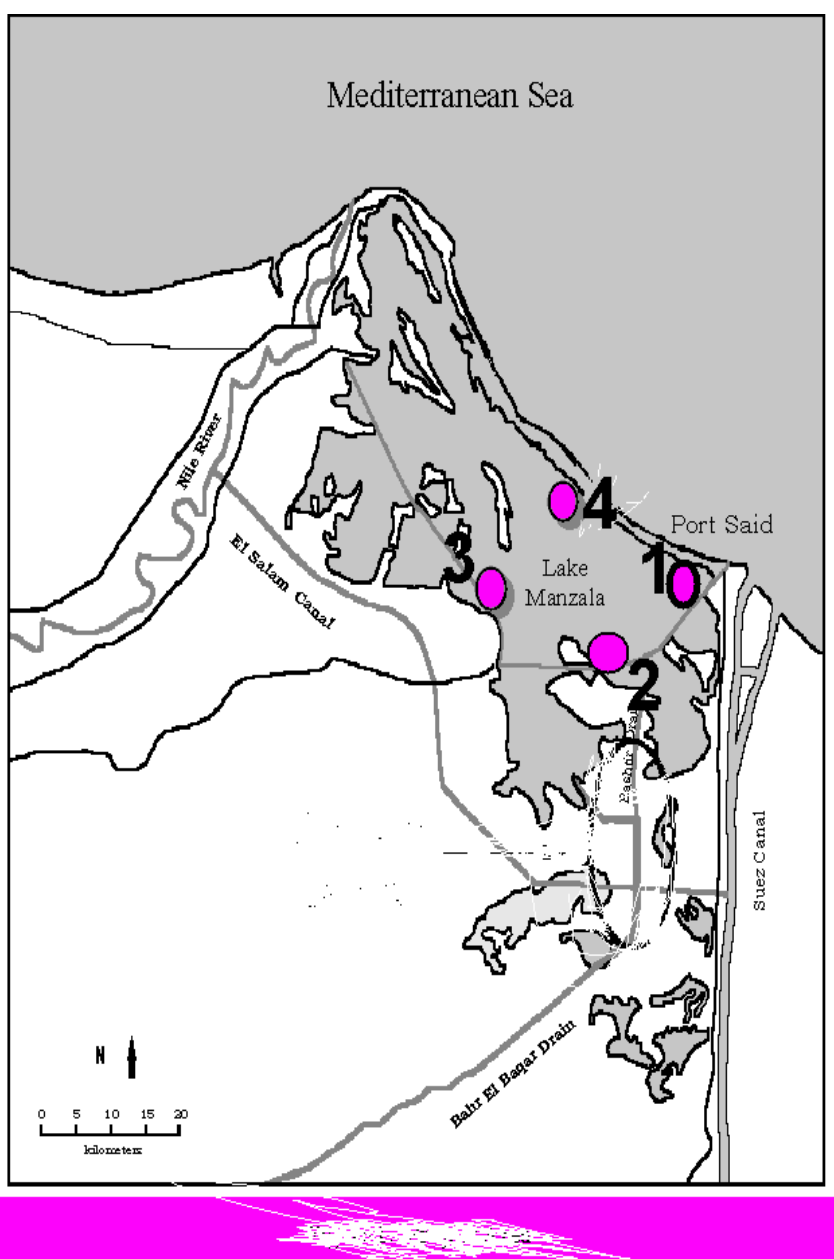

Figure 1: Map of Lake Manzala, showing the three different sampling sites and their respective sources of pollution. method. The fish were dissected and $1 \mathrm{~g}$. of the intestinal contents was aseptically stripped out with sterile forceps. Samples of gill lamellae and intestinal contents $(1 \mathrm{~g})$ were aseptically re-suspended in $100 \mathrm{ml}$ of $0.1 \% \mathrm{~W} / \mathrm{V}$ chilled peptone water ( $\mathrm{pH} 7.0$ ), homogenized and poured with different dilutions into petri dishes.

\section{Physicochemical characteristics of water samples}

Physicochemical characteristic of each water sample was evaluated in the field. The temperature of the water samples was determined by using a mercury thermometer. The $\mathrm{pH}$ values were determined using a recombination of a pH electrode (Eil Series 1180) and a pH meter (Eill, Model 7030), which was calibrated against $\mathrm{pH} \mathrm{4,7}$ and 9 buffers. The levels of dissolved oxygen in the water samples were determined using the Oxygen Meter model YSI 58. The chemical analysis to determine the total suspended solids (TSS), ammonia, nitrates, Sulphates, Alkalinity, calcium, magnesium and chloride levels were done using the recommended standard methods of water analysis $(\mathrm{mg} / \mathrm{L})$.

\section{Microbiological analysis}

Counts of total viable bacteria (TVB), Total anaerobic and total anaerobic spore formers were determined utilizing nutrient agar. Total coliforms and of faecal coliforms Shigella spp on S. S. agar. Vibrio spp. on T.C.B.S agar. Aeromonas spp. on Aeromonas differential agar. Counts of water $\mathrm{cfu} / \mathrm{ml}$ and of fish $\mathrm{cfu} / \mathrm{g}$.

Bacterial isolates were further identified by taking typical colonies from the agar medium and identifying them according to the recommended API $20 \mathrm{E}$ system (bioMerieux) for identification of the family Enterobacteriaceae.

\section{Statistical analysis}

The correlation matrix is the relationship between a number of data sets that are scaled to be independent of the unit of measurement. It is used to determine whether data sets move together; that is whether large values of one set are associated with large values of the other (positive correlation); whether small values of one set are associated with large values of the other (negative correlation); or whether the values of the sets are unrelated [7].

\section{Resistance to antimicrobial agents}

The disc diffusion method was used to find antimicrobial resistance. The bacterial strains were grown overnight in nutrient broth, then 1 $\mathrm{ml}$ of the broth was poured into a Petri dish and finally the nutrient agar media (50 C) were poured. Different antibiotic discs (Oxoid) were inserted into the plates, before the complete solidification of the media and the plates were incubated at $37^{\circ} \mathrm{C}$ for $24 \mathrm{hrs}$. The presence of a colony was an indication of the resistance of the bacteria to the following antibiotics; Chloramphenicol $(30 \mu \mathrm{g})$, Ampicillin $(10 \mu \mathrm{g})$, Penicillin G $(10 \mu \mathrm{g})$, Streptomycin $(10 \mu \mathrm{g})$, Gentamycin $(10 \mu \mathrm{g})$, Cefotaxime $(5 \mu \mathrm{g})$, Rifampcin $(5 \mu \mathrm{g})$ and Tetracyclin $(30 \mu \mathrm{g})$.

\section{Isolation of plasmid DNA}

The alkaline lysis method was used in mini preparation [8]. For antibiotic resistant bacterial strains isolated from water and fish samples.

\section{Results}

Physicochemichal parameters and bacteriological characteristics, showed seasonal variations in water samples in different sites

El Kapoty site: The statistical analysis of the data in El-Kapoty site 
Citation: Zaky MMM, Salem MAM (2015) Environmental Factors Influencing Antibiotic Resistant Bacterial Pathogens in Polluted Lake Manzala, Egypt. J Bacteriol Parasitol 6: 249. doi: 10.4172/2155-9597.1000249

Page 3 of 6

showed that there was a very strong positive (+ve) correlation between temperature and TVB, T. An, S.S, Aermonas and Vibrio ( $\mathrm{r}=0.99,0.92$, $0.97,0.92$ and $0.97 ; \mathrm{p}<0.05)$ respectively. Also, there was a strong positive (+ve) correlation between temperature and T.C, F.C and F.S $(\mathrm{r}=0.70,0.86$ and $0.84 ; \mathrm{p}<0.05)$ respectively (Table 1$)$

The statistical analysis showed that there was a very strong negative (-ve) correlation between $\mathrm{pH}$ and T.C $(\mathrm{r}=-0.94, \mathrm{p}<0.05)$. Also, there was a strong negative (-ve) correlation between $\mathrm{pH}$ and Vibrio $(\mathrm{r}=-0.70$, $\mathrm{p}<0.05)$. Also, there was a modest negative $(-\mathrm{ve})$ correlation between $\mathrm{pH}$ and TVB, T. An and S.S $(\mathrm{r}=-0.66,0.65$ and $0.52 ; \mathrm{p}<0.05)$ respectively (Table 2).

Bashtier site: The statistical analysis of the data in Bashtier site showed that there was a very strong positive (+ve) correlation between temperature and Vibrio $(\mathrm{r}=0.96 ; \mathrm{p}<0.05)$. Also, there was a strong positive (+ve) correlation between temperature and T.V.B, T. An, T.C, S.S and Aermonas $(\mathrm{r}=0.86,0.87,0.77$ and $0.86 ; \mathrm{p}<0.05)$ respectively (Table 3).

The statistical analysis showed that there was a strong negative (-ve) correlation between $\mathrm{pH}$ and T.V.B, T. An, T.C, S.S, Aermonas and Vibrio $(\mathrm{r}=-0.77,-0.79,-0.87,-0.73,-0.72$ and $-0.76 ; \mathrm{p}<0.05)$ respectively (Table 4$)$.

Mataryia site: The statistical analysis of the data on Mataryia site showed that there was a very strong positive (+ve) correlation between temperature and TVB and Aermonas ( $\mathrm{r}=0.94$ and $0.92 ; \mathrm{p}<0.05)$ respectively. Also, there was a strong positive $(+\mathrm{ve})$ correlation between temperature and T.C and Vibrio $(\mathrm{r}=0.78$ and $0.80 ; \mathrm{p}<0.05)$ respectively (Table 5$)$.

\begin{tabular}{|c|c|c|c|c|c|}
\hline Parameters & Autumn & Spring & Summer & Winter & Average \pm SD \\
\hline Temp. & 22.7 & 20 & 29.3 & 13.8 & $21.5 \pm 6.4$ \\
\hline $\mathbf{p H}$ & 7 & 8.4 & 8.3 & 9.5 & $8.3 \pm 1.0$ \\
\hline E.C & 3983.3 & 2383 & 1716.7 & 1225 & $2327.0 \pm 1201.9$ \\
\hline D.O & 2.7 & 1.8 & 1.6 & 1.7 & $2.0 \pm 0.5$ \\
\hline T.S.S & 110.3 & 173 & 179.6 & 95.5 & $139.6 \pm 42.9$ \\
\hline T.D.S & 16026.7 & 9846 & 17882 & 8304 & $13014.7 \pm 4654.5$ \\
\hline $\mathbf{N H}_{4}^{+}-\mathbf{N}$ & 0.7 & 0.2 & 0 & 0.8 & $0.4 \pm 0.4$ \\
\hline $\mathbf{N O}_{\mathbf{3}^{-}}^{-\mathbf{N}}$ & 0.2 & 0.2 & 0 & 0.1 & $0.1 \pm 0.1$ \\
\hline $\mathbf{S O}_{\mathbf{4}}^{-}$ & 2003.1 & 1600.6 & 1718 & 1415.9 & $1684.4 \pm 246.2$ \\
\hline $\mathbf{C l}^{-}$ & 5636.8 & 4959 & 7873 & 3980 & $5612.2 \pm 1653.5$ \\
\hline $\mathbf{A l k a l}^{-}$ & 253.3 & 207.5 & 205 & 252.5 & $229.6 \pm 27.0$ \\
\hline $\begin{array}{c}\text { Total } \\
\mathbf{H a r d n e s s}^{-}\end{array}$ & 3046.7 & 2200 & 3314.7 & 1850 & $2602.9 \pm 691.1$ \\
\hline $\mathbf{C a}^{++}$ & 344.2 & 282.6 & 326 & 344.7 & $324.4 \pm 29.2$ \\
\hline $\mathbf{M g}^{++}$ & 531.7 & 363.4 & 608.3 & 240.8 & $436.1 \pm 165.5$ \\
\hline
\end{tabular}

Table 1: The seasonal variations of different physicochemical parameters from El-Kapoty Site.

\begin{tabular}{|c|c|c|c|c|c|}
\hline Parameters & Autumn & Spring & Summer & Winter & Average \pm SD \\
\hline T.V.B & 6500 & 3500 & 9200 & 350 & $4887.5 \pm 3817.1$ \\
\hline T. An & 4200 & 700 & 5500 & 150 & $2637.5 \pm 2619.0$ \\
\hline T. An. sp & 5 & 220 & 22 & 1.5 & $62.1 \pm 105.6$ \\
\hline T.C & 1200 & 300 & 780 & 15 & $573.8 \pm 523.4$ \\
\hline F.C & 48 & 25 & 440 & 0 & $128.3 \pm 208.8$ \\
\hline F.S & 1.7 & 0 & 40 & 0 & $13.9 \pm 22.6$ \\
\hline S.S & 88.3 & 40.8 & 140 & 22 & $72.8 \pm 52.8$ \\
\hline Aermonas & 78.7 & 25.5 & 190 & 21.5 & $78.9 \pm 78.5$ \\
\hline Vibrio & 63.7 & 39.3 & 76 & 11 & $47.5 \pm 28.7$ \\
\hline
\end{tabular}

Table 2: The seasonal variations of the count of different Bacterial species in ElKapoty Site.

\begin{tabular}{|c|c|c|c|c|c|}
\hline Parameters & Winter & Summer & Spring & Autumn & Average \pm SD \\
\hline Temp. & 14.5 & 29.7 & 20.8 & 23.2 & $22.1 \pm 6.3$ \\
\hline $\mathbf{p H}$ & 8.9 & 8.2 & 8.4 & 8.6 & $8.5 \pm 0.3$ \\
\hline E.C & 975 & 1516.7 & 2100 & 2812.3 & $1851.0 \pm 788.5$ \\
\hline D.O & 1.4 & 1.4 & 1.75 & 3.1 & $1.9 \pm 0.8$ \\
\hline T.S.S & 76.5 & 83 & 114.7 & 45.7 & $80.0 \pm 28.3$ \\
\hline T.D.S & 3572 & 11542.7 & 5225.3 & 6488 & $6707.0 \pm 3437.8$ \\
\hline $\mathbf{N H}_{4}^{+}-\mathbf{N}$ & 1.4 & 0.2 & 0.2 & 0.14 & $0.5 \pm 0.6$ \\
\hline $\mathbf{N O}_{3}^{-}-\mathbf{N}$ & 0 & 0.06 & 0.2 & 0.1 & $0.1 \pm 0.1$ \\
\hline $\mathbf{S O}_{\mathbf{4}}^{-}$ & 630.2 & 3180.2 & 949.4 & 2138.7 & $1724.6 \pm 1167.5$ \\
\hline $\mathbf{C l}^{-}$ & 1541.2 & 4779.5 & 2159.3 & 1966.5 & $2611.6 \pm 1468.1$ \\
\hline Alkal $^{-}$ & 302.5 & 191.7 & 212.5 & 276.7 & $245.9 \pm 52.3$ \\
\hline $\begin{array}{c}\text { Total } \\
\text { Hardness }\end{array}$ & 500 & 2146.7 & 1215 & 1860 & $1430.4 \pm 732.5$ \\
\hline $\mathbf{C a}^{++}$ & 200.4 & 331.3 & 284.5 & 307 & $280.8 \pm 56.9$ \\
\hline $\mathbf{M g}^{++}$ & 218.7 & 321 & 122.8 & 265.9 & $232.1 \pm 84.0$ \\
\hline
\end{tabular}

Table 3: The seasonal variations of different physicochemical parameters in Bashtier Site.

\begin{tabular}{|c|c|c|c|c|c|}
\hline Parameters & Winter & Summer & Spring & Autumn & Average \pm SD \\
\hline T.V.B & 3000 & 43000 & 6000 & 6400 & $14600.0 \pm 18994.0$ \\
\hline T. An & 600 & 24000 & 3200 & 3300 & $7775.0 \pm 10888.6$ \\
\hline T. An. sp & 1.5 & 25 & 120 & 18.3 & $41.2 \pm 53.5$ \\
\hline T.C & 8 & 150 & 70 & 1 & $57.3 \pm 69.2$ \\
\hline F.C & 80.5 & 68 & 45 & 0 & $48.4 \pm 35.4$ \\
\hline F.S & 0 & 0 & 0 & 0.3 & $0.1 \pm 0.2$ \\
\hline S.S & 37 & 320 & 39.5 & 70 & $116.6 \pm 136.4$ \\
\hline Aermonas & 42 & 310 & 39.5 & 84.3 & $119.0 \pm 129.0$ \\
\hline Vibrio & 8.5 & 110 & 34.7 & 80.3 & $58.4 \pm 45.4$ \\
\hline
\end{tabular}

Table 4: The seasonal variations of the count of different Bacterial species in Bashtier Site.

\begin{tabular}{|c|c|c|c|c|c|}
\hline Parameters & Autumn & Spring & Summer & Winter & Average \pm SD \\
\hline Temp. & 23.3 & 20.5 & 28.7 & 15 & $21.9 \pm 5.7$ \\
\hline $\mathrm{pH}$ & 8.06 & 8.5 & 7.9 & 7.5 & $8.0 \pm 0.4$ \\
\hline E.C & 1708.3 & 1616.7 & 991.7 & 880 & $1299.2 \pm 423.7$ \\
\hline D.O & 1.75 & 1.6 & 1.4 & 1.9 & $1.7 \pm 0.2$ \\
\hline T.S.S & 41.3 & 98.7 & 49.3 & 53.5 & $60.7 \pm 25.8$ \\
\hline T.D.S & 3039.3 & 3257.3 & 2951.3 & 2863 & $3027.7 \pm 169.1$ \\
\hline $\mathrm{NH}_{4}{ }^{+}-\mathrm{N}$ & 1.05 & 0.6 & 0 & 4 & $1.4 \pm 1.8$ \\
\hline $\mathrm{NO}_{3}^{-}-\mathrm{N}$ & 0.3 & 0.2 & 0.2 & 0.5 & $0.3 \pm 0.1$ \\
\hline $\mathrm{SO}_{4}^{--}$ & 907.4 & 1048.6 & 947.5 & 635.5 & $884.8 \pm 176.5$ \\
\hline $\mathrm{Cl}^{-}$ & 953 & 1181.9 & 1905 & 1113.7 & $1288.4 \pm 422.1$ \\
\hline Alkal & 321.7 & 262.5 & 276.7 & 312.5 & $293.4 \pm 28.3$ \\
\hline $\begin{array}{c}\text { Total } \\
\text { Hardness }\end{array}$ & 856.7 & 870 & 756.7 & 870 & $838.4 \pm 54.8$ \\
\hline $\mathrm{Ca}^{++}$ & 176.1 & 262.5 & 165.6 & 256.3 & $215.1 \pm 51.4$ \\
\hline $\mathbf{M g}^{++}$ & 101.2 & 52.3 & 83.5 & 55.9 & $73.2 \pm 23.3$ \\
\hline
\end{tabular}

Table 5: The seasonal variations of different physicochemical parameters in Mataryia Site.

The statistical analysis showed that there was a very strong negative (-ve) correlation between $\mathrm{pH}$ and F.S $(\mathrm{r}=-0.95, \mathrm{p}<0.05)$. Also, there was a strong positive (+ve) correlation between $\mathrm{pH}$ and F.C $(\mathrm{r}=0.70$, $\mathrm{p}<0.05$ ) (Table 6).

El Gamil site: The statistical analysis showed that there was a very strong positive (+ve) correlation between temperature and Vibrio $(\mathrm{r}=0.99 ; \mathrm{p}<0.05)$. Also, there was a strong positive (+ve) correlation between temperature and T.V.B, T. AN sp, and Aermonas $(\mathrm{r}=0.85,0.87$, and $0.77 ; \mathrm{p}<0.05$ ) respectively (Table 7 ). 
Citation: Zaky MMM, Salem MAM (2015) Environmental Factors Influencing Antibiotic Resistant Bacterial Pathogens in Polluted Lake Manzala, Egypt. J Bacteriol Parasitol 6: 249. doi: 10.4172/2155-9597.1000249

\begin{tabular}{|c|c|c|c|c|c|}
\hline Parameters & Autumn & Spring & Summer & Winter & Average \pm SD \\
\hline T.V.B & 29000 & 20000 & 92000 & 1700 & $35675.0 \pm 39230.4$ \\
\hline T.An & 16000 & 120000 & 11000 & 1000 & $37000.0 \pm 55683.6$ \\
\hline T.An.sp & 3.3 & 34 & 8.3 & 10 & $13.9 \pm 13.7$ \\
\hline T.C & 78.3 & 210 & 430 & 80 & $199.6 \pm 165.5$ \\
\hline F.C & 1.7 & 560 & 150 & 8.5 & $180.1 \pm 262.4$ \\
\hline F.S & 1.7 & & 0.7 & 21 & $7.8 \pm 11.4$ \\
\hline S.S & 430 & 130 & 450 & 91.5 & $275.4 \pm 190.9$ \\
\hline Aeromonas & 180 & 130 & 180 & 100 & $147.5 \pm 39.5$ \\
\hline Vibrio & 110 & 73.3 & 89 & 17 & $72.3 \pm 39.8$ \\
\hline
\end{tabular}

Table 6: The seasonal variations of the count of different Bacterial species in Mataryia Site.

The statistical analysis showed that there was a strong negative (-ve) correlation between $\mathrm{pH}$ and F.S $(\mathrm{r}=-0.88, \mathrm{p}<0.05)$ (Table 8).

\section{Bacteriological characteristics of fishes}

Identification of bacterial strains: A total of 90 isolates were identified using the API 20E system, 21 different strains with different ratios.

Plasmid DNA profiling: Plasmid profiling for the different strain, which are resistant to antibiotics, contains a variety of plasmids (Figure 2).

\section{Discussion}

There are many studies that have looked at the polluted condition of Lake Manzala and the deterioration of the physicochemical and bacteriological conditions which have adversely affected the lake's ecosystem including the evolution of the lake water from marine brackish

\begin{tabular}{|c|c|c|c|c|c|}
\hline Parameters & Autumn & Spring & Summer & Winter & Average \pm SD \\
\hline Temp. & 24.7 & 22.7 & 31 & 15 & $23.4 \pm 6.6$ \\
\hline $\mathrm{pH}$ & 8.5 & 8.1 & 7.9 & 8 & $8.1 \pm 0.3$ \\
\hline E.C & 3950 & 2566.7 & 1533.3 & 1350 & $2350.0 \pm 1193.6$ \\
\hline D.O & 2.7 & 1 & 1.4 & 2.8 & $2.0 \pm 0.9$ \\
\hline T.S.S & 176.7 & 332 & 125.7 & 302.5 & $234.2 \pm 98.8$ \\
\hline T.D.S & 21676.7 & 11881.3 & 14060 & 19267 & $16721.3 \pm 4529.3$ \\
\hline $\mathrm{NH}_{4}^{+}-\mathrm{N}$ & 2.8 & 1 & 0.9 & 1.2 & $1.5 \pm 0.9$ \\
\hline $\mathrm{NO}_{3}-\mathrm{N}$ & 0.3 & 0.2 & 0.1 & 0 & $0.2 \pm 0.1$ \\
\hline $\mathrm{SO}_{4}^{--}$ & 4203 & 1959.7 & 1145.2 & 1748.5 & $2264.1 \pm 1337.9$ \\
\hline $\mathrm{Cl}^{-}$ & 4779.3 & 4948.9 & 4500.9 & 5176.9 & $4851.5 \pm 284.9$ \\
\hline Alkal & 333.3 & 392.5 & 300 & 400 & $356.5 \pm 48.0$ \\
\hline $\begin{array}{c}\text { Total } \\
\text { Hardness }\end{array}$ & 2746.7 & 2445 & 2333.3 & 3020 & $2636.3 \pm 309.7$ \\
\hline $\mathrm{Ca}^{++}$ & 1349.3 & 288.5 & 316.6 & 348.7 & $575.8 \pm 516.3$ \\
\hline $\mathbf{M g}^{++}$ & 462 & 419.3 & 234.2 & 522.9 & $409.6 \pm 124.4$ \\
\hline
\end{tabular}

Table 7: The seasonal variations of different physicochemical parameters El Gamil Site.

\begin{tabular}{|c|c|c|c|c|c|}
\hline Parameters & Autumn & Spring & Summer & Winter & Average \pm SD \\
\hline T.An & 38000 & 130000 & 100000 & 3000 & $67750.0 \pm 57714.1$ \\
\hline T.An.sp & 60.7 & 49 & 330 & 2 & $110.4 \pm 148.6$ \\
\hline T.C & 110 & 190 & 60 & 24.5 & $96.1 \pm 71.7$ \\
\hline F.C & 23 & 200 & 100 & 0.5 & $80.9 \pm 90.1$ \\
\hline F.S & 18.3 & 5 & 6.7 & 1 & $8.7 \pm 8.8$ \\
\hline S.S & 230 & 50.2 & 150 & 40.5 & $117.7 \pm 89.8$ \\
\hline Aeromonas & 220 & 43.2 & 290 & 88 & $160.3 \pm 114.5$ \\
\hline Vibrio & 69.3 & 63 & 120 & 15 & $66.8 \pm 43.0$ \\
\hline
\end{tabular}

Table 8: The seasonal variations of the count of different Bacterial species in El Gamil Site.

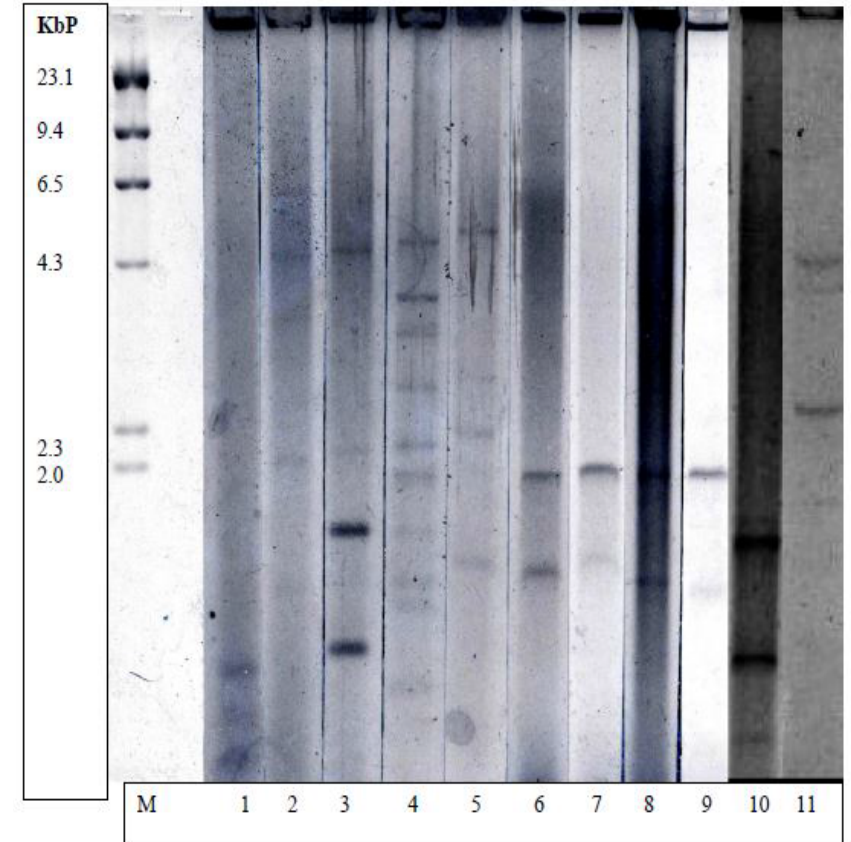

Figure 2: Plasmid DNA profiling, of different bacterial strains, isolated from wate and fish of Lake Manzala. M) $\lambda$ DNA digested with Hind III, 1) Pseudomonas sp., 2) Pasturella sp;, 3) Erwinia sp.; 4) Citrobacter freundi, 5) Sphomonas paucimobilis; 6) Stentrophomonas maltophilia; 7) Stentrophomonas maltophilia; 8) Proteus mirabilis; 9) Eschericia coli; 10) Aeromonas hydrophila; 11) Aeromonas sobria

to brackish fresh. The eutrophication of Lake Manzala has been in response to increased freshwater inputs and nutrients from agricultural run-off and urban waste disposal [9]. This has resulted in a dynamic ecology of Lake ecosystem, which was noted in the changing of the fish population from a mixed brackish water species with a population that is primarily constituted of a single species of Tilapia [10].

The effluents of fresh water from drains like the Bahr El-Bakar drain, oppose the current from the Mediterranean Sea resulting in slow water movement to the point where the Lake is almost stagnant or at least without currents. The heavy loads of suspended solids and organic matter have raised the bed of the lake and have created shallow water depths. The highest densities of microbial populations are noteworthy, particularly those of bacteria.

This study revealed high records of pollutants, like ammonia and nitrates, the presence of these can be explained by the anoxic conditions created by the depletion of oxygen. In addition high suspended particles whether of organic or mineral origin, adsorb bacteria to their surfaces. The adsorption of debris particles not only provide microbes a more favorable nutritional environment than those found in free water but also neutralize inhibitory and toxic substances. Thus the suspended particles have a favorable effect on the bacterial growth. This in line with other studies on pollution of Lake Manzala $[11,12]$.

Fecal coliform counts, well known water pollution indicators, were performed on the different anatomical parts of the fish samples from the Kapoty and Mataryia areas. These counts were used in the study to assess and understand the level of pollution of Lake Manzala (Table 9).

The classical method for the enumeration of heterotrophic bacteria was used in the study; this method accomplishes the separation of 
Citation: Zaky MMM, Salem MAM (2015) Environmental Factors Influencing Antibiotic Resistant Bacterial Pathogens in Polluted Lake Manzala, Egypt. J Bacteriol Parasitol 6: 249. doi: 10.4172/2155-9597.1000249

Page 5 of 6

\begin{tabular}{|c|c|c|c|c|c|c|c|c|c|c|c|}
\hline Site & $\begin{array}{l}\text { Part of } \\
\text { fish }\end{array}$ & $\begin{array}{c}\text { No. of } \\
\text { tests }\end{array}$ & T.V.B & T.An & T.An. Sp & T.C & F.C & F.S & S.S & $\begin{array}{c}\text { Aeromonas } \\
\text { sp. }\end{array}$ & Vibrio sp. \\
\hline & Intestine & 4 & $142250 \pm 11638$ & $75332.5 \pm 74978$ & $1122 \pm 1233$ & $41732 \pm 44685$ & $8662 \pm 9293$ & $26500 \pm 41868$ & $31750 \pm 29420$ & $30757 \pm 46863$ & $11270 \pm 14256$ \\
\hline \multirow[t]{3}{*}{ Bashtier } & gills & 4 & $60750 \pm 33519$ & $47750 \pm 44214$ & $427 \pm 320$ & $2762 \pm 1829$ & $3272.5 \pm 2385$ & $24083 \pm 21494$ & $4320 \pm 4535$ & $21817 \pm 17707$ & $2280 \pm 2569$ \\
\hline & flesh & 4 & $44212 \pm 50719$ & $36200 \pm 30193$ & $6025 \pm 10079$ & $745 \pm 727$ & $2000 \pm 2041$ & $12443 \pm 18742$ & $17987 \pm 16038$ & $15142 \pm 13189$ & $1757 \pm 1622$ \\
\hline & Intestine & 4 & $94750 \pm 74186$ & $808250 \pm 1461293$ & $106170 \pm 189827$ & $17800 \pm 19163$ & $5000 \pm 9345$ & $10143 \pm 11460$ & $89000 \pm 47511$ & $26250 \pm 22276$ & $18875 \pm 30123$ \\
\hline \multirow[t]{2}{*}{ Mataryia } & gills & 4 & $138750 \pm 198761$ & $46850 \pm 37444$ & $10007 \pm 15486$ & $3557 \pm 5678$ & $1987.5 \pm 2666$ & $7673 \pm 5136$ & $58000 \pm 46209$ & $22892 \pm 15807$ & $2375 \pm 2098$ \\
\hline & flesh & 4 & $30737 \pm 42541$ & $23212.5 \pm 23114$ & $5362 \pm 9098$ & $1150 \pm 1618$ & $717.5 \pm 1435$ & $3576 \pm 3706$ & $16925 \pm 17407$ & $14782 \pm 19433$ & $1010 \pm 1166$ \\
\hline
\end{tabular}

Table 9: The average and standard deviation values of different bacterial counts in three parts of fish samples in two sampling sites (Bashtier and Mataryia).

individual microbes from the multitude of micro-organisms in a natural microbial community allowing for the individual phenotypes to be determined, which is the basis of the pure culture method and are the mainstay of microbiology [13].

The deterioration of the environmental conditions in Lake Manzala can be attributed to the people inhabiting the region and their role as an element of the ecosystem. The complaints and ever increasing recorded cases of diarrhea, gastroenteritis, kidney failure and other diseases may be partially explained by the aforementioned lake condition. The Lake Manzala water samples as well as the fish samples were found to have very high pathogenic bacteria contents; some of these pathogens produce dangerous extracellular products that are virulent. It is worthy to note that many of these pathogens belong to different taxonomic groups like the families Enterobacteriaceae and Vibrionaceae, with species such as E. coli, Salmonella spp., Shigella spp., Vibrio spp. and Aeromonas spp. These pathogens have been reported to exist in Lake Manzala [14,15].

The statistical analysis of previous studies revealed a strong correlation between counts of Aeromonas spp. and fecal coliforms in Lake Manzala, a brackish water environment. Thus Aeromonas spp. can be a powerful tool for the assessment of the microbial pollution in the brackish water environment [6].

A study [16,17] revealed that Aeromonas hydrophila exhibited

\begin{tabular}{|l|l|c|c|c|}
\hline No & Strain & Source & $\begin{array}{c}\text { Number of } \\
\text { isolates }\end{array}$ & Percentage \\
\hline 1 & Acinetobacter sp. & Water & 1 & $1.1 \%$ \\
\hline 2 & Erwinia sp. & Water & 4 & $4.4 \%$ \\
\hline 3 & Stentrophomonas maltophilia & Fish & 2 & $2.2 \%$ \\
\hline 4 & Aeromonas hydrophila & Fish & 16 & $17.7 \%$ \\
\hline 5 & Aeromonas sobria & Fish & 15 & $16.6 \%$ \\
\hline 6 & Chrysomonas lutcola & Water & 1 & $1.1 \%$ \\
\hline 7 & Flavobacterium oryzihabitans & Water & 2 & $2.2 \%$ \\
\hline 8 & Favobacterium odoratum & Water & 1 & $1.1 \%$ \\
\hline 9 & Flavobacterium maningosepticum & Water & 1 & $1.1 \%$ \\
\hline 10 & Bacillus sp. & Water & 8 & $8.8 \%$ \\
\hline 11 & Serratia sp. & Water & 1 & $1.1 \%$ \\
\hline 12 & Vibrio sp. & Water & 1 & $1.1 \%$ \\
\hline 13 & Pseudomonas sp. & Water & 1 & $1.1 \%$ \\
\hline 14 & Pasteurella sp. & Water & 1 & $1.1 \%$ \\
\hline 15 & Klebsiella pneumonia & Fish & 3 & $3.3 \%$ \\
\hline 16 & Citrobacter freundii & Fish & 2 & $2.2 \%$ \\
\hline 17 & Sphomonas paucimebilis & Fish & 1 & $1.1 \%$ \\
\hline 18 & Proteus mirabilis & Fish & 9 & $10 \%$ \\
\hline 19 & E. coli & Fish & 10 & $11.1 \%$ \\
\hline 20 & Enterobacter amnignus & Fish & 1 & $1.1 \%$ \\
\hline 21 & Streptococcus sp. & 3 & $3.3 \%$ \\
\hline & 10. & & 1 \\
\hline
\end{tabular}

Table 10: Identification of bacterial strain from samples of Lake Manzala water and fish. a resistance to a number of antibiotics, particularly to ampicillin and penicillin. The resistance is an indication of the presence of $\beta$-Lactamases which are common in bacterial pathogens found in polluted water environment and the Egyptian environment. These environments are rich in nutrients like calcium, magnesium and chlorides; there is a strong correlation between the existence of these nutrients and Aeromonas spp. counts in brackish water environment [1].

Statistical analysis indicates that Temperature and $\mathrm{pH}$ are two main factors influencing bacterial pathogens in Lake Manzala. This study, revealed the occurrence of different multi-drug resistant strains of Pseudomonas sp., E. coli, Proteus mirabilis and Stentrophomonas maltophilia. The latter was isolated for the first time from polluted water in Egypt through this study; the organism is an important opportunistic pathogen that is isolated worldwide from the rhizosphere of some plants, waste water and drinking tap water $[18,19]$ (Table 10).

Stentrophomonas maltophilia is used in biotechnology for biological control of plant pathogens and bioremediation [20]. Recently it has been recorded however, that its unregulated presence in natural environments

\begin{tabular}{|c|c|c|c|c|c|c|c|c|c|}
\hline No. & $\begin{array}{l}\text { ले } \\
\text { के }\end{array}$ & 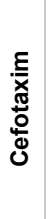 & 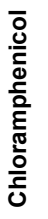 & 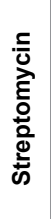 & 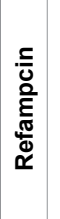 & 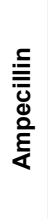 & 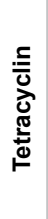 & 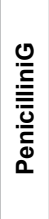 & 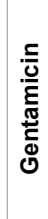 \\
\hline 1 & Acinetobacter sp. & $\mathrm{s}$ & $s$ & $\mathrm{R}$ & $\mathrm{s}$ & $\mathrm{R}$ & $\mathrm{s}$ & $\mathrm{R}$ & $\mathrm{s}$ \\
\hline 2 & Erwinia sp. & $\mathrm{s}$ & $\mathrm{R}$ & $\mathrm{s}$ & $\mathrm{s}$ & $\mathrm{s}$ & $\mathrm{R}$ & $\mathrm{s}$ & $\mathrm{s}$ \\
\hline 3 & Stentrophomonas maltophilia & $\mathrm{S}$ & $S$ & $\mathrm{R}$ & $S$ & $\mathrm{R}$ & $\mathrm{S}$ & $\mathrm{R}$ & S \\
\hline 4 & Aeromonas hydrophila & $\mathrm{s}$ & S & $\mathrm{R}$ & $\mathrm{R}$ & $\mathrm{R}$ & $\mathrm{R}$ & $\mathrm{R}$ & S \\
\hline 5 & Aeromonas sobria & $\mathrm{s}$ & $\mathrm{R}$ & $\mathrm{R}$ & $\mathrm{s}$ & $\mathrm{R}$ & $\mathrm{R}$ & $\mathrm{R}$ & $\mathrm{R}$ \\
\hline 6 & Chrysomonas lutcola & $\mathrm{s}$ & $S$ & $S$ & $\mathrm{R}$ & $\mathrm{R}$ & $\mathrm{s}$ & $\mathrm{R}$ & S \\
\hline 7 & Flavobacterium oryzihabitans & $\mathrm{s}$ & s & $\mathrm{R}$ & $\mathrm{s}$ & $\mathrm{R}$ & $\mathrm{s}$ & $\mathrm{R}$ & $\mathrm{s}$ \\
\hline 8 & Favobacterium odoratum & $\mathrm{s}$ & $S$ & $S$ & $S$ & $\mathrm{~s}$ & $\mathrm{R}$ & $S$ & S \\
\hline 9 & Flavobacterium maningosepticum & $\mathrm{s}$ & $\mathrm{R}$ & S & S & $\mathrm{R}$ & $\mathrm{s}$ & $\mathrm{R}$ & S \\
\hline 10 & Bacillus sp. & $\mathrm{R}$ & $\mathrm{R}$ & $\mathrm{R}$ & $\mathrm{R}$ & $\mathrm{R}$ & $\mathrm{R}$ & $\mathrm{R}$ & $\mathrm{R}$ \\
\hline 11 & Serratia sp. & $\mathrm{s}$ & $s$ & $\mathrm{~s}$ & $\mathrm{~s}$ & $\mathrm{~s}$ & $\mathrm{~s}$ & $\mathrm{~s}$ & $\mathrm{~s}$ \\
\hline 12 & Vibrio sp. & $\mathrm{s}$ & $\mathrm{R}$ & $\mathrm{R}$ & $S$ & $\mathrm{R}$ & $\mathrm{S}$ & $\mathrm{R}$ & $\mathrm{R}$ \\
\hline 13 & Pseudomonas sp. & $s$ & $S$ & $S$ & $S$ & $\mathrm{R}$ & $\mathrm{s}$ & $\mathrm{R}$ & S \\
\hline 14 & Pasteurella sp. & $\mathrm{s}$ & $S$ & $S$ & $S$ & $\mathrm{R}$ & $\mathrm{S}$ & $\mathrm{R}$ & S \\
\hline 15 & Klebsiella pneumonia & $\mathrm{s}$ & $\mathrm{R}$ & $\mathrm{R}$ & $\mathrm{R}$ & $\mathrm{R}$ & $\mathrm{s}$ & $\mathrm{R}$ & S \\
\hline 16 & Citrobacter freundii & $s$ & $\mathrm{R}$ & $S$ & $\mathrm{R}$ & $\mathrm{R}$ & $\mathrm{s}$ & $\mathrm{R}$ & $\mathrm{R}$ \\
\hline 17 & Sphomonas paucimebilis & $\mathrm{s}$ & $S$ & $S$ & $S$ & $\mathrm{~s}$ & $\mathrm{~S}$ & $S$ & S \\
\hline 18 & Proteus mirabilis & $\mathrm{R}$ & $\mathrm{R}$ & $\mathrm{R}$ & $\mathrm{R}$ & $\mathrm{R}$ & $\mathrm{s}$ & $\mathrm{R}$ & $\mathrm{R}$ \\
\hline 19 & E. coli & $\mathrm{R}$ & $\mathrm{R}$ & $\mathrm{R}$ & $\mathrm{R}$ & $\mathrm{R}$ & $\mathrm{R}$ & $\mathrm{R}$ & $R$ \\
\hline 20 & Enterobacter amnignus & $\mathrm{R}$ & $S$ & $S$ & $\mathrm{R}$ & $\mathrm{R}$ & $\mathrm{R}$ & $\mathrm{R}$ & S \\
\hline 21 & Streptococcus sp & $\mathrm{R}$ & $\mathrm{R}$ & $\mathrm{R}$ & $\mathrm{R}$ & $S$ & $\mathrm{R}$ & $\mathrm{R}$ & $\mathrm{R}$ \\
\hline
\end{tabular}

Table 11: The antibiotic resistance pattern of bacterial strains isolated of fish of Lake Manzala ( $\mathrm{S}=$ Susceptible; $\mathrm{R}=$ Resistant). 
Citation: Zaky MMM, Salem MAM (2015) Environmental Factors Influencing Antibiotic Resistant Bacterial Pathogens in Polluted Lake Manzala, Egypt. J Bacteriol Parasitol 6: 249. doi: 10.4172/2155-9597.1000249

Page 6 of 6

is dramatically increasing, causing bacteraemia, pneumonia, infections of the urinary tract and soft tissues, as well as many nosocomial infections in children and adults $[21,22]$. The presence of bacterial pathogens in water and fish of Lake Manzala, poses a risk to the health of the populations residing along the lake in this important coastal area of Egypt. The organism harbours a DNA plasmid and is B-Lactamase resistant characteristics which are of primary importance in the epidemiology of infectious diseases and clinical (nosocomial) infections. More studies which focuses on the transmission of opportunistic bacterial pathogens are needed (Table 11).

\section{Conclusion}

In this study, physicochemical characteristics revealed high pollution condition of the lake water. A bacterial count of fish parts indicates that fish of the lake not suitable for human consumption. Bacterial Identification of water and fish samples revealed the occurrence of different bacterial pathogenic species in the lake.

Aeromonas hydrophila and Aeromonas sobria are two dominant species in Lake Manzala. Statistical analysis revealed that temperature and $\mathrm{pH}$ are two important factors influencing bacterial counts Lake Manzala.

Antibiogram showed variation of resistance of bacterial pathogens to different antibiotics. Plasmid DNA profiling indicates that antibiotic resistant pathogens are genetically active in the environment.

Lake Manzala is considered a source of many bacterial pathogens which are risk for human health in this area of Egypt.

More efforts should be done for prevention and rehabilitation lake Manzala, to avoid dangerous human diseases in this important part of Egypt.

\section{References}

1. Zaky MM (2006) Environmental factors influencing multi-drug resistant and harboring plasmid DNA Aeromonas hydrophila isolated from polluted water of Lake Manzala, Egypt. Proceedings of the 19th laps International Conference on Environment, Health and Sustainable Development, Sept. 11-16, Alexandria, Egypt, pp: 159-160.

2. Abbassy MS, Ibrahim HZ, Abdel-Kader HM (2003) Persistent organochlorine pollutants in the aquatic ecosystem of Lake Manzala, Egypt. Bull Environ Contam Toxicol 70: 1158-1164.

3. El-Sarangawy DA (1990) Pathogenic indicators of water in six wastewater resources in Lake Manzala, North Egypt. Part I, Bahr El-Bakar. Zagazig Vet J 18: 26-34.

4. El-Gaber GA, Naguib M, El-Aziz E (1997) Vibrio species infections in Orechromis niloticus and Mugil cephalus, sodium chloride tolerence pathogenecity, serological relatedness and antibiograms sensitivity of recovered vibrios. Vet Med J 45: 87-99.

5. Sulayman $\mathrm{ZI}$ (1999) Antibiogram of some bacteria contaminating Tilapia fish at El-Manzala Lake in Port-Said Governorate. Vet Med J 27: 19-27.

6. Zaky MM, Salem A, Mansour FA (2005) Environmental and health significance of toxigenic Aeromonas sobria and Aeromonas hydrophila in polluted water of Lake Manzala, Egypt. Proceedings of the 26th African Health Congress.
7. Fowler J, Cohen L (1996) Practical statistics for field Biology. John Willy and Sons, England.

8. Maniatis T, Fritsch EF, Sambrook J (1982) Molecular Cloning a Laboratory Manual. Cold Spring Harbor Laboratory, New York, USA, pp: 149-171.

9. Shaheen $A H$, Youssef SF (1978) The effect of the cessation of Nile flood on the hydrographic features of lake Manzala, Egypt. Arch Hydrobiol 48: 339-367.

10. Khalil MT (1990) The physical and chemical environment of Lake Manzala Egypt. Hydrobiologia 196: 193-199.

11. Hamed YA, Abdelmoneim TS, Elkiki MH, Hassan MA, Berndtsson R (2013) Assessment of heavy metals pollution and microbial contamination in water Sedemints and fish of Lake Manzala, Egypt. Life science journal 10: 86-99.

12. Abdelhamid AM, El-Deweny MEM, El-Barbary MI (2013) Bacteriological status of ashtom El-Gamil protected area. J Aquat Biol \& Fish 17: 11-23.

13. Levin MA, Seidler RJ, Rogul M (1992) Microbial Ecology (1stedn.) McGraw-Hill, New York, pp: 11-25.

14. Urbina D, Arzuza O, Young G, Parra E, Castro R, et al. (2003) Rotavirus type A and other enteric pathogens in stool samples from children with acute diarrhea on the Colombian northern coast. Int Microbiol 6: 27-32.

15. Saleh AR, Shawky ZS, Elsayed Abou-El-Geit (2013) Microbiological water quality and bacterial infections among Tilapia fish of Lake Manzala, Egypt. International journal of environment \& water 2: 75-85.

16. Dumontet S, Pasquale V, Mancino M, Normanno G, Krovacek K (2003) Incidence and characterisation of Aeromonas spp. in environmental and human samples in southern Italy. New Microbiol 26: 215-225.

17. Pianietti A, Sabatini L, Bruscolini F, Chiaverini F, Cecchetti G (2004) Faeca contamination indicators, Salmonella, Vibrio and Aeromonas in water used for the irrigation of agricultural products. Epidemiol. Infect 132: 231-238.

18. Critchley MM, Cromar NJ, McClure NC, Fallowfield HJ (2003) The influence of the chemical composition of drinking water on cuprosolvency by biofilm bacteria. J Appl Microbiol 94: 501-507.

19. Hoefel D, Monis PT, Grooby WL, Andrews S, Saint CP (2005) Profiling bacteria survival through a water treatment process and subsequent distribution system. J Applied Microbiol 99: 175-186.

20. Berg G, Roskot N, Smalla K (1999) Genotypic and phenotypic relationships between clinical and environmental isolates of Stenotrophomonas maltophilia. J Clin Microbiol 37: 3594-3600.

21. Boktour M, Hanna H, Ansari S, Bahna B, Hachem R, et al. (2006) Centra venous catheter and Stenotrophomonas maltophilia bacteremia in cancer patients. Cancer 106: 1967-1973.

22. del Toro MD, Rodríguez-Baño J, Martínez-Martínez L, Pascual A Pérez-Canoa $R$, et al. (2006) Epidemiology, clinical features and prognosis of infections due to Stenotrophomonas maltophilia. Enferm Infecc Microbiol Clin 24: 4-9. 